\title{
PENGARUH LATAR BELAKANG KELUARGA TERHADAP KESADARAN LINGKUNGAN MAHASISWA DI FAKULTAS KEGURUAN DAN ILMU PENDIDIKAN UNIVERSITAS SYIAH KUALA
}

\section{THE INFLUENCE OF FAMILY BACKGROUND ON THE ENVIRONMENTAL WARENESS OF STUDENTS IN SYIAH KUALA UNIVERSITY}

\author{
Iqbal Ridha $^{1}$, Muhammad Haikal ${ }^{2}$, Heri Fajri ${ }^{3}$ \\ ${ }^{1}$ Jurnalis Lingkungan Hidup \\ ${ }^{2}$ Prodi Pendidikan Sejarah FKIP, Universitas Syiah Kuala \\ ${ }^{3}$ Prodi Pendidikan Sejarah FKIP, Universitas Jabal Ghafur \\ E-mail: iqbalridha93@gmail.com
}

Disetujui: 27/11/2019

\begin{abstract}
ABSTRAK
Penelitian ini bertujuan untuk mengetahui pengaruh latar belakang keluarga terhadap kesadaran lingkungan mahasiswa Fakultas Keguruan dan Ilmu Pendidikan (FKIP) Universitas Syiah Kuala. Jenis penelitian yang digunakan adalah deskriptif kuantitatif dengan metode survey analitis. Responden penelitian yakni mahasiswa semester empat pada program studi pendidikan kimia, fisika, geografi dan sejarah. Penentuan sampel menggunakan teknik nonprobability sampling dengan tipe purposive sampling. Jumlah sampel sebanyak 100 orang. Data dikumpulkan menggunakan angket. Hasil penelitian ditemukan bahwa terdapat hubungan antara variabel latar belakang dengan kesadaran lingkungan, walaupun korelasinya lemah. Ada 5 variabel sosiografi yang memiliki hubungan dengan kesadaran lingkungan yakni variabel pekerjaan ayah, pekerjaan ibu, penghasilan ayah, penghasilan ibu dan tempat tinggal. Dari 5 variabel tersebut, 3 variabel memiliki pengaruh secara parsial (faktor tunggal) yakni pekerjaan ibu, penghasilan ibu dan status tempat tinggal.
\end{abstract}

Kata kunci: Keluarga, kesadaran, lingkungan, FKIP, Sejarah 


\begin{abstract}
This study aims to determine the effect of family background on environmental awareness of the Faculty of Teacher Training and Education (FKIP) Syiah Kuala University. This type of research is quantitative descriptive analytical survey methods. The research respondents are fourth semester students in chemistry, physics, geography and history education courses. Determination of the sample using nonprobability sampling techniques with the type of purposive sampling. The number of samples is 100 people. Data was collected using a questionnaire. The results found that there is a relationship between background variables with environmental awareness, although the correlation is weak. There are 5 sociographic variables that have a relationship with environmental awareness namely the father's occupation, mother's occupation, father's income, mother's income and residence. From these 5 variables, 3 variables have a partial effect (single factor) namely mother's occupation, mother's income and status of residence.
\end{abstract}

Keywords: Family background, environmental awareness

\title{
PENDAHULUAN
}

Persoalan lingkungan menjadi isu yang cukup populer. Lingkungan merupakan bagian integral yang tak terpisahkan dari kehidupan manusia (Hasan, dkk., 2009). Kerusakan lingkungan yang terjadi di berbagai tempat menunjukkan bahwa kemampuan masyarakat Indonesia dalam mengelola lingkungan atau sumberdaya milik bersama (common property) masih lemah (Pranadji, 2005). Hal ini juga menunjukkan bahwa dari tingkat nasional hingga komunal telah terjadi kerusakan nilai budaya.

Manusia harus menjaga stabilitas lingkungan hidup dan menyadari bahwa mereka diturunkan Allah SWT sebagai khalifah yang harus mengelola bumi dengan bijak. Pengelolaan alam yang buruk, kurangnya pemahaman dan kesadaran untuk memelihara lingkungan akan memberi dampak signifikan bagi kehidupan manusia (Djoehaeni, 2014).

Lingkungan kerap berada di bawah tekanan seiring meningkatnya faktor sosioekonomi masyarakat. Beragam persoalan yang terjadi misalnya pencemaran lingkungan, pemanasan global, kerusakan hutan dan lain sebagainya kini telah menjadi masalah internasional. Pada tahun 2000, para pimpinan dunia menandatangani Millenium Development Goals (MDGs) atau Deklarasi Milennium di New York. Salah satu poin dalam MDGs 
tersebut menyebut bahwa isu lingkungan perlu diperhatikan semua pihak.

Aminrad, dkk. (2010) menyatakan di akhir abad 20, kepedulian lingkungan tumbuh lebih besar, tidak hanya di negara-negara maju, tetapi juga di beberapa negara berkembang. Dampak kerusakan lingkungan menjadi begitu terasa sehingga para pemimpin negara menjadi khawatir akan akibat yang ditimbulkan. Persoalan lingkungan bahkan sering diangkat menjadi tajuk utama di berbagai media massa.

Aktifitas manusia yang tanpa diiringi kesadaran lingkungan cenderung merusak lingkungan. Menurut Ali (2015) kesadaran lingkungan dapat dikelompokkan dalam dua aspek yaitu persepsi masalah dan kecenderungan perilaku untuk melindungi lingkungan. Sulastri (2016) menyatakan pengetahuan merupakan prasyarat untuk kesadaran lingkungan. Tindakan rasional terhadap lingkungan adalah terjemahan dari pengetahuan yang dimiliki oleh individu. Perilaku sadar lingkungan termasuk dalam kelompok nilai-nilai moral universal yang sepatutnya dimiliki warga dunia.

Kesadaran dan pemahaman lingkungan yang tepat akan membentuk sikap yang tepat terhadap persoalan lingkungan. Sebaliknya jika seseorang tidak menyadari dan paham akan kondisi lingkungan tentu akan memperburuk situasi lingkungan. Menurut Perkasa dkk. (2017) dalam Programme for International
Student Assessment (PISA) telah dirumuskan beberapa indikator kesadaran lingkungan yakni sebagai berikut:

1. Mengetahui dan sadar terhadap isu serta permasalahan lingkungan (awareness of environmental issues), dijelaskan sebagai pengukuran tentang kapasitas siswa dalam memahami dan mengetahui sumber permasalahan lingkungan sekitarnya;

2. Persepsi terhadap isu tentang lingkungan (perception of environmental issues), diuraikan sebagai tingkat kepedulian siswa terhadap masalah lingkungan sekitar;

3. Kepercayaan diri dalam menyelesaikan permasalahan lingkungan dan berkontribusi untuk keberlangsungan lingkungan hidup (Environment Optimism).

Menurut Kalantari, dkk. (2007) umumnya literatur menunjukkan bahwa pendidikan adalah variabel kunci pada sikap lingkungan. Pemahaman tentang masalah lingkungan modern membutuhkan tingkat pengetahuan lingkungan yang tinggi, pengetahuan lingkungan yang tinggi berkorelasi dengan tingkat pendidikan yang tinggi.

Menurut Hasan dkk. (2009) ketika pengetahuan tentang lingkungan meningkat, sikap positif terhadap lingkungan secara tidak langsung diperluas. Adeolu, dkk. (2014) menyatakan sikap negatif masyarakat terhadap lingkungan turut mempengaruhi lembaga pendidikan, banyak hal yang sudah dirancang 
dengan baik tetapi di lapangan mengalami kemandekan.

Menurut Boiyo, dkk. (2015) masalah dan tanggungjawab sosial memainkan peran kunci dalam menentukan sikap lingkungan masyarakat. Sulastri (2016) menyatakan kepedulian terhadap lingkungan merupakan salah satu nilai pembentuk karakter yang telah diidentifikasi bersumber dari agama, pancasila, budaya dan tujuan pendidikan nasional. Lingkungan kerap berada di bawah tekanan seiring meningkatnya faktor sosio-ekonomi masyarakat. Maka dalam penelitian ini akan dikaji bagaiman mengenai pengaruh latar belakang keluarga terhadap kesadaran lingkungan mahasiswa.

\section{METODE PENELITIAN}

Penelitian ini bersifat deskriptif kuantitatif dengan pendekatan survey. Menurut Morissan (2012) survey merupakan metode yang sangat baik untuk mengukur sikap dan orientasi suatu masyarakat melalui kegiatan jajak pendapat. Di sisi lain dapat dijadikan sebagai kerangka konseptual untuk mempelajari banyak variabel misalnya pemahaman, kesadaran, kemauan dan partisipasi suatu kelompok terhadap hal tertentu.

Penelitian survei yang dilakukan tergolong survey analitis. Dalam penelitian ini peneliti berusaha mencari bagaimana pengaruh latar belakang keluarga terhadap kesadaran lingkungan mahasiswa. Penentuan sampel menggunakan teknik nonprobability sampling (sampel nonprobabilitas) dengan tipe purposive sampling (sampel terpilih).
Teknik nonprobabilty sampling merupakan teknik penarikan sampel berdasarkan pertimbangan khusus dengan anggapan bermanfaat dan representatif (Morissan, 2012). Menurut Efffendi dan Tukiran (2012), dalam survey informasi dikumpulkan dari sampel untuk mewakili seluruh populasi. Ini berbeda dengan sensus yang informasinya dikumpulkan dari seluruh populasi.

Sampel ditujukan pada mahasiswa semester 4 pada prodi pendidikan kimia, fisika, geografi dan sejarah. Mahasiswa pada tahap ini telah memiliki karakteristik diantaranya stabilitas kepribadian mulai meningkat, pandangan lebih realistis tentang dirinya sendiri dan lingkungan hidupnya, kemampuan untuk menghadapi segala permasalahan secara lebih matang dan gejolak emosi mulai berkurang.

Total populasi dari empat prodi yang terpilih berjumlah 244 orang. Penetuan jumlah sampel menggunakan teknik quota sampling, dimana sampel diambil dengan cara menetapkan jumlah tertentu sebagai target yang harus dipenuhi. Maka jumlah sampel yang ditetapkan yakni 100 responden, setiap prodi diwakili 25 mahasiswa angkatan 2016.

Penelitian ini dilakukan di lingkungan FKIP Unsyiah. Isi angket terbagi dalam tiga kelompok item yakni item pengetahuan, sikap dan perilaku. Kategori pengetahuan terdiri dari 19 item, sikap 22 item sedang perilaku 46 item, kesemua item tersebut telah diuji validitas dan reabilitas. Angket ini bersifat tertutup dan menggunakan skala likert. Skala tanggapan mulai dari 1 (belum menyadari) sampai 5 (menyadari dan siap melakukan), khusus untuk perilaku digunakan skala 1 sampai 4 .

Tabel 1 Kisi-kisi angket pengukuran kesadaran lingkungan 


\begin{tabular}{|c|c|c|c|c|}
\hline No & Variabel & Subvariabel & $\begin{array}{l}\text { Jumlah } \\
\text { Item }\end{array}$ & Total \\
\hline \multirow[t]{6}{*}{1} & \multirow[t]{6}{*}{$\begin{array}{l}\text { Pengetahu } \\
\text { an }\end{array}$} & $\begin{array}{ll}\text { 1. } & \begin{array}{l}\text { Lingkungan } \\
\text { hidup }\end{array}\end{array}$ & 2 & \multirow[t]{6}{*}{19} \\
\hline & & 2. $\begin{array}{l}\text { Pemanasan } \\
\text { global }\end{array}$ & 5 & \\
\hline & & $\begin{array}{l}\text { 3. Sumber energi } \\
\text { alternatif }\end{array}$ & 3 & \\
\hline & & $\begin{array}{l}\text { 4. Pengelolaan } \\
\text { sampah dan } \\
\text { limbah }\end{array}$ & 3 & \\
\hline & & $\begin{array}{ll}\text { 5. } & \text { Slogan/gaya } \\
\text { hidup peduli } \\
\text { lingkungan }\end{array}$ & 3 & \\
\hline & & $\begin{array}{ll}6 . & \text { Pencemaran } \\
& \text { lingkungan } \\
\text { oleh bahan } \\
\text { kima organik }\end{array}$ & 3 & \\
\hline \multirow[t]{6}{*}{2} & \multirow[t]{6}{*}{ Sikap } & $\begin{array}{ll}\text { 1. Lingkungan } \\
\text { hidup }\end{array}$ & 2 & \multirow[t]{6}{*}{22} \\
\hline & & 2. $\begin{array}{l}\text { Pemanasan } \\
\text { global }\end{array}$ & 5 & \\
\hline & & 3. $\begin{array}{l}\text { Sumber energi } \\
\text { alternatif }\end{array}$ & 1 & \\
\hline & & $\begin{array}{ll}\text { 4. } & \text { Pengelolaan } \\
\text { sampah dan } \\
\text { limbah }\end{array}$ & 5 & \\
\hline & & $\begin{array}{ll}\text { 5. } & \text { Slogan/gaya } \\
\text { hidup peduli } \\
\text { lingkungan }\end{array}$ & 5 & \\
\hline & & $\begin{array}{ll}\text { 6. } & \text { Pencemaran } \\
\text { lingkungan } \\
\text { oleh bahan } \\
\text { kima organik }\end{array}$ & 4 & \\
\hline \multirow[t]{6}{*}{3} & \multirow[t]{6}{*}{ Perilaku } & $\begin{array}{ll}\text { 1. } & \text { Lingkungan } \\
\text { hidup }\end{array}$ & 10 & \multirow[t]{6}{*}{46} \\
\hline & & 2. $\begin{array}{l}\text { Pemanasan } \\
\text { global }\end{array}$ & 4 & \\
\hline & & $\begin{array}{l}\text { 3. Sumber energi } \\
\text { alternatif }\end{array}$ & 3 & \\
\hline & & $\begin{array}{l}\text { 4. Pengelolaan } \\
\text { sampah dan } \\
\text { limbah }\end{array}$ & 5 & \\
\hline & & $\begin{array}{ll}\text { 5. } & \text { Slogan/gaya } \\
\text { hidup peduli } \\
\text { lingkungan }\end{array}$ & 18 & \\
\hline & & $\begin{array}{ll}\text { 6. } & \text { Pencemaran } \\
\text { lingkungan } \\
\text { oleh bahan } \\
\text { kima organik }\end{array}$ & 6 & \\
\hline
\end{tabular}

Tabel 2 Deskripsi dari poin-poin jawaban skala likert

\begin{tabular}{|c|l|l|c|}
\hline $\begin{array}{c}\text { Tipe } \\
\text { Skala }\end{array}$ & \multicolumn{1}{|c|}{ Pengetahuan } & \multicolumn{1}{|c|}{ Sikap } & Perilaku \\
\hline 1 & $\begin{array}{l}\text { Tidak pernah } \\
\text { mendengar }\end{array}$ & $\begin{array}{l}\text { Belum } \\
\text { menyadari }\end{array}$ & $\begin{array}{c}\text { Tidak } \\
\text { pernah }\end{array}$ \\
\hline 2 & $\begin{array}{l}\text { Pernah tahu tapi } \\
\text { tidak dapat } \\
\text { menjelaskan dengan } \\
\text { rinci }\end{array}$ & $\begin{array}{l}\text { Sudah } \\
\text { menyadari } \\
\text { tapi belum } \\
\text { memiliki }\end{array}$ & Jarang \\
\hline
\end{tabular}

\begin{tabular}{|c|l|l|l|}
\hline & & $\begin{array}{l}\text { keinginan } \\
\text { untuk } \\
\text { melakukannya }\end{array}$ & \\
\hline 3 & $\begin{array}{l}\text { Mengerti dan } \\
\text { mampu } \\
\text { mendiskusikan }\end{array}$ & $\begin{array}{l}\text { Menyadari } \\
\text { tapi belum } \\
\text { yakin mampu } \\
\text { melakukannya }\end{array}$ & Sering \\
\hline 4 & $\begin{array}{l}\text { Mengerti, mampu } \\
\text { mendiskusikan dan } \\
\text { menghubungkan } \\
\text { dengan berbagai isu } \\
\text { lainnya }\end{array}$ & $\begin{array}{l}\text { Menyadari } \\
\text { dan sudah } \\
\text { berencana } \\
\text { untuk } \\
\text { melakukannya }\end{array}$ & Selalu \\
\hline 5 & Sangat menguasai & $\begin{array}{l}\text { Menyadari } \\
\text { dan siap untuk } \\
\text { melakukannya }\end{array}$ & \\
\hline
\end{tabular}

(Sumber: Sulastri, 2016)

Hasil analisis berdasarkan skala diharapkan dapat memaparkan tingkat kesadaran lingkungan mahasiswa. Dalam angket tersebut juga berisi biodata responden yang wajib diisi. Dari biodata inilah faktor-faktor latar belakang keluarga dapat duji pengaruhnya terhadap kesadaran lingkungan. Data yang dikumpulkan dari angket kemudian diolah melalui metode statistik deskriptif tertentu, langkah perhitungannya sebagai berikut:

1. Mencari skor ideal atau skor maksimum untuk kesadaran lingkungan.

2. Menjumlahkan skor yang diperoleh setiap subjek. Jumlah skor subjek merupakan penjumlahan dari skor subjek tiap item.

3. Mencari persentase hasil skala kesadaran lingkungan dengan rumus:

$$
\text { Skor }=\frac{\text { Jumlah Skor tiap Subjek }}{\text { Skor ideal }} \times 100 \%
$$

\section{HASIL PENELITIAN DAN PEMBAHASAN}

\section{Data Latar Belakang Mahasiswa}

Berdasarkan rekapitulasi data ditemukan $72 \%$ responden berjenis kelamin perempuan dan $28 \%$ responden berjenis kelamin laki-laki. Dari segi pendidikan orang tua, untuk ayah $66 \%$ berpendidikan SD-SMA dan $34 \%$ berpendidikan D1-S3, kemudian untuk ibu $68 \%$ berpendidikan 
SD-SMA dan 32\% berpendidikan D1-S3. Mayoritas status pendidikan orang tua responden paling tinggi lulusan SMA, sedang yang mengecap perguruan tinggi lebih sedikit. Lebih jelasnya dapat dilihat pada Gambar 1 .

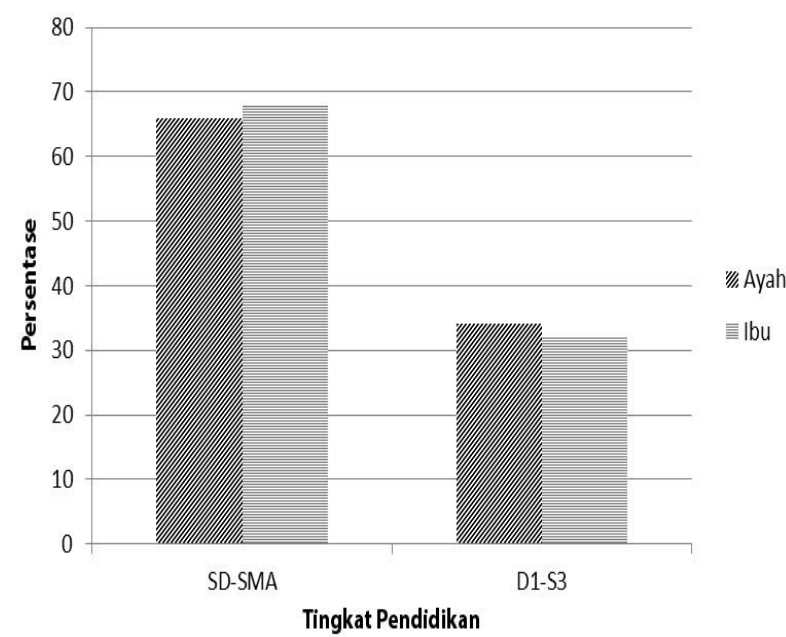

Gambar 1 Persentase tingkat pendidikan orang tua mahasiswa

Kemudian dari segi pekerjaan orang tua, untuk ayah $29 \%$ bekerja sebagai PNS dan $71 \%$ non PNS. Untuk ibu 27\% bekerja sebagai PNS dan 73\% non PNS. Persentase data pekerjaan orang tua dapat dilihat pada Gambar 2.

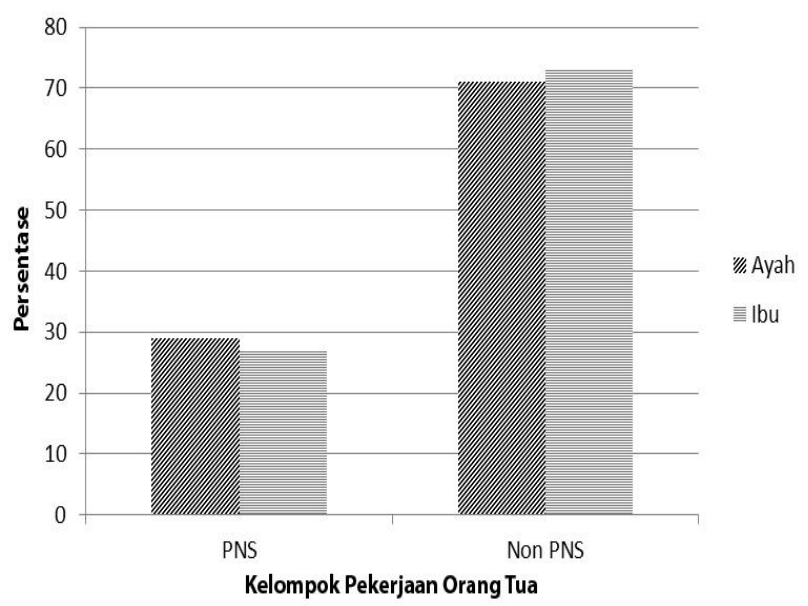

Gambar 2 Persentase tingkat profesi orang tua mahasiswa
Kemudian dari segi jumlah pendapatan orang tua, untuk ayah, $32 \%$ berpenghasilan kurang dari 1 juta rupiah, 64\% berpenghasilan 1-4 juta rupiah dan $7 \%$ lebih dari 4 juta rupiah. Untuk ibu $61 \%$ berpenghasilan kurang dari 1 juta rupiah dan $39 \%$ berpenghasilan 1-4 juta rupiah. Persentase pendapatan orang tua dapat dilihat pada Gambar 3 .

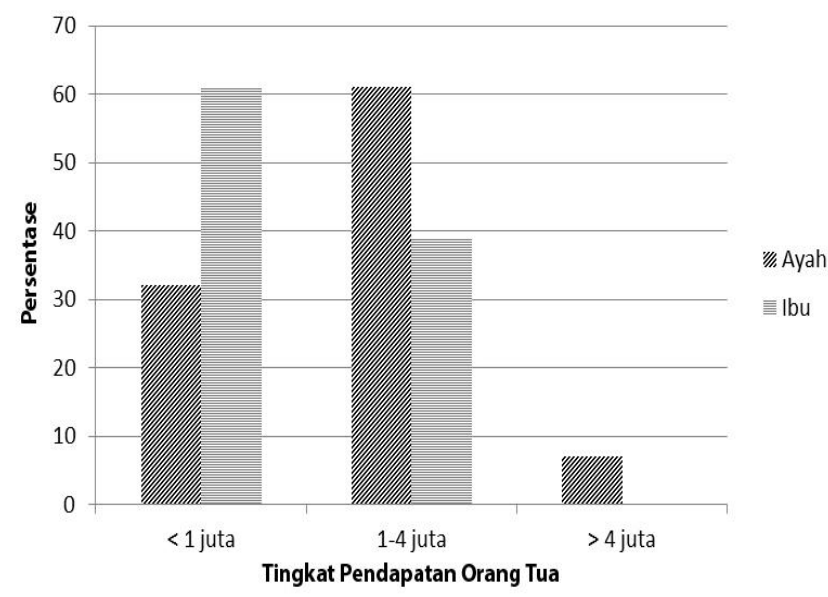

Gambar 3 Persentase tingkat pendapatan orang tua mahasiswa

Dari segi keikutsertaan organisasi, $80 \%$ mahasiswa terlibat dalam organisasi, sedang $17 \%$ tidak ikut dalam organisasi. Mengenai status tempat tinggal, 25\% mahasiswa tinggal bersama orang tua/saudara, 69\% tinggal di kos/asrama dan 6\% tinggal di rumah pribadi. Perinciannya dapat dilihat pada Gambar 4 dan 5.

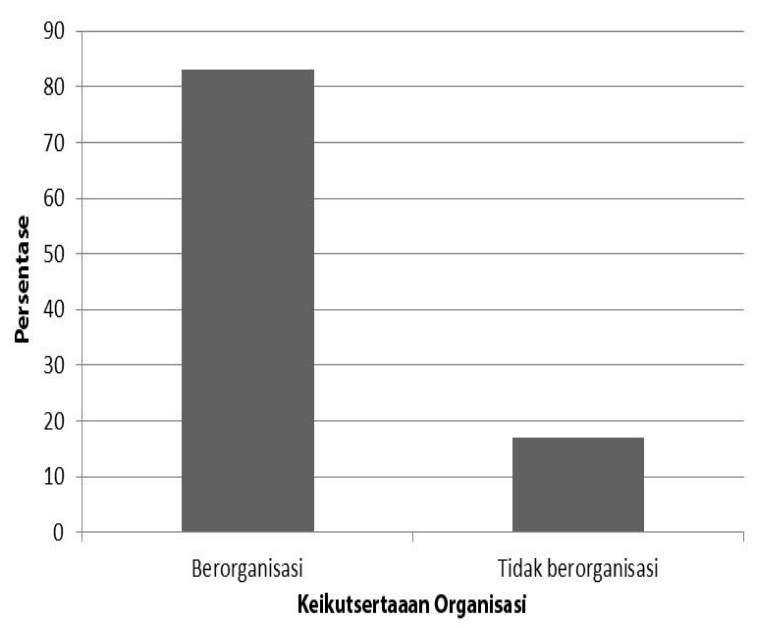


Gambar 4 Persentase keterlibatan mahasiswa dalam organisasi

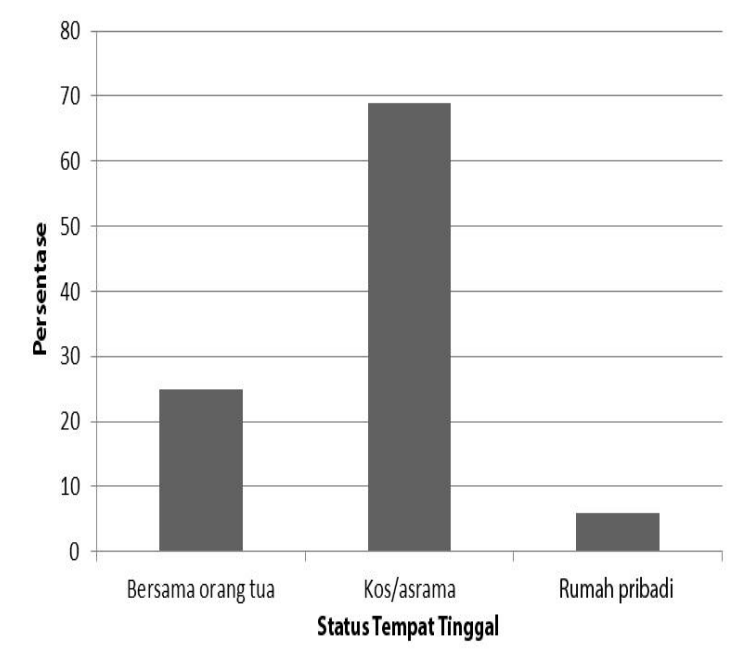

Gambar 5 Persentase status tempat tinggal mahasiswa

Untuk mengetahui tingkat hubungan antara variabel terikat (kesadaran lingkungan) dengan variabel bebas (latar belakang mahasiswa) dapat dilihat pada nilai R (nilai korelasi berganda). Nilai $\mathrm{R}$ yang didapat yakni 0,414 , angka tersebut mendekati 0 . Hal ini menunjukkan korelasi antara variabel terikat dengan variabel bebas memiliki hubungan yang lemah.

Dalam analisis regresi linear berganda juga didapat nilai $\mathrm{F}$ hitung sebesar 2,071 dan nilai signifikansi 0,040. Uji F digunakan untuk menguji signifikansi pengaruh beberapa variabel bebas terhadap variabel terikat. Jika F hitung $>$ F tabel dan nilai signifikansi $<0,05$ maka disimpulkan terdapat hubungan antara latar belakang dengan kesadaran lingkungan. Nilai F tabel yakni 1,99, dan nilai signifikansi < 0,05 maka dapat dinyatakan terdapat hubungan antara variabel terikat dengan variabel bebas walaupun lemah.

Untuk mengetahui hubungan satu persatu variabel bebas dengan variabel terikat dapat dilihat pada nilai standardized coefficients. Nilai tersebut merupakan nilai koefisien yang telah terstandarisasi. Jika nilai standardized coefficients semakin mendekati 0 maka hubungannya semakin lemah (Priyatno, 2014). Hasil analisis menunjukkan bahwa hanya 5 variabel yang memiliki hubungan dengan kesadaran lingkungan walaupun lemah.

Kelima variabel tersebut adalah pekerjaan ayah $(0,041)$, pekerjaan ibu $(0,250)$, penghasilan ayah $(0,044)$, penghasilan ibu $(0,268)$ dan variabel tempat tinggal $(0,200)$. Sedangkan selebihnya tidak memiliki hubungan karena nilai standardized coefficients dibawah 0.

Pengaruh variabel bebas terhadap variabel terikat secara parsial dapat dilihat pada perbandingan nilai $\mathrm{t}$ hitung dengan $\mathrm{t}$ tabel. Pengujian ini juga untuk melihat seberapa signifikan hubungan antar variabel. Nilai $\mathrm{t}$ tabel pada signifikansi 0,05/2 dengan derajat kebebasan $(\mathrm{df})=90$ yakni 1,987. Jika $\mathrm{t}$ hitung $>\mathrm{t}$ tabel dan signifikansi $<0,05$ maka secara parsial terdapat pengaruh antara variabel bebas dengan variabel terikat.

Jika nilai $t$ hitung positif artinya berpengaruh positif. Dari analisis diketahui bahwa hanya variabel pekerjaan ibu, penghasilan ibu dan status tempat tinggal yang memiliki pengaruh secara parsial terhadap kesadaran lingkungan. Variabel selebihnya tidak ada yang berpengaruh secara parsial. Nilai t hitung positif mengartikan bahwa jika ketiga variabel tersebut meningkat, maka kesadaran lingkungan juga akan meningkat. Hasil analisis dapat dilihat pada Tabel 3.

Tabel 3 Hasil uji t

\begin{tabular}{|c|l|c|c|}
\hline No & \multicolumn{1}{|c|}{ Variabel } & $\begin{array}{c}\text { Nilai t } \\
\text { hitung }\end{array}$ & $\begin{array}{c}\text { Nilai } \\
\text { Signifika } \\
\text { nsi }\end{array}$ \\
\hline 1 & Jenis Kelamin & $-0,130$ & 0,897 \\
\hline 2 & $\begin{array}{l}\text { Pendidikan } \\
\text { Ayah }\end{array}$ & $-1,046$ & 0,298 \\
\hline 3 & Pendidikan Ibu & $-0,897$ & 0,372 \\
\hline 4 & Pekerjaan Ayah & 0,422 & 0,674 \\
\hline 5 & Pekerjaan Ibu & 2,514 & 0,014 \\
\hline 6 & $\begin{array}{l}\text { Penghasilan } \\
\text { Ayah }\end{array}$ & 0,441 & 0,660 \\
\hline
\end{tabular}




\begin{tabular}{|c|l|c|c|}
\hline 7 & Penghasilan Ibu & 2,618 & 0,010 \\
\hline 8 & $\begin{array}{l}\text { Keanggotaan } \\
\text { Organisasi }\end{array}$ & $-0,670$ & 0,505 \\
\hline 9 & $\begin{array}{l}\text { Status Tempat } \\
\text { Tinggal }\end{array}$ & 2,021 & 0,046 \\
\hline
\end{tabular}

Untuk memperkuat temuan sebelumnya, langkah selanjutnya yakni melakukan analisis jalur. Proses analisis jalur berguna untuk mengetahui estimasi tingkat kepentingan (magnitude) dan signifikansi hubungan sebab akibat hipotetikal dalam seperangkat variabel.

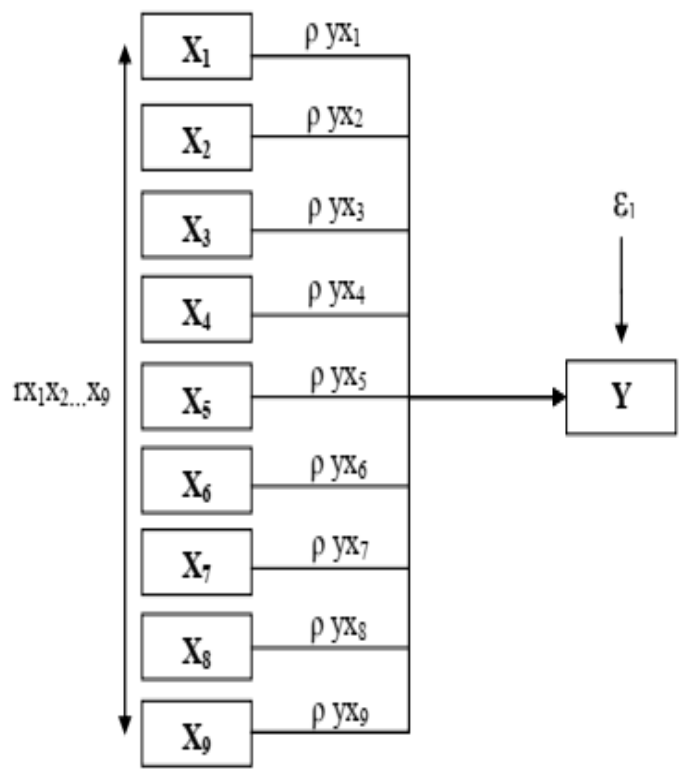

Gambar 7 Diagram jalur pengaruh antar variabel

Tabel 4 Nilai standardized coefficients dari analisis jalur

\begin{tabular}{|c|l|c|c|}
\hline No & Variabel & $\begin{array}{c}\text { Standa } \\
\text { rdized } \\
\text { Coeffic } \\
\text { ients } \\
\text { (Beta) }\end{array}$ & Keterangan \\
\hline 1 & Jenis Kelamin & $-0,010$ & $\begin{array}{c}\text { Tidak } \\
\text { berpengaruh }\end{array}$ \\
\hline 2 & $\begin{array}{l}\text { Pendidikan } \\
\text { Ayah }\end{array}$ & $-0,105$ & $\begin{array}{c}\text { Tidak } \\
\text { berpengaruh }\end{array}$ \\
\hline 3 & $\begin{array}{l}\text { Pendidikan } \\
\text { Ibu }\end{array}$ & $-0,089$ & $\begin{array}{c}\text { Tidak } \\
\text { berpengaruh }\end{array}$ \\
\hline 4 & $\begin{array}{l}\text { Pekerjaan } \\
\text { Ayah }\end{array}$ & 0,043 & $\begin{array}{c}\text { Berpengaruh } \\
\text { lemah }\end{array}$ \\
\hline
\end{tabular}

\begin{tabular}{|c|l|c|c|}
\hline 5 & Pekerjaan Ibu & 0,250 & $\begin{array}{c}\text { Berpengaruh } \\
\text { lemah }\end{array}$ \\
\hline 6 & $\begin{array}{l}\text { Penghasilan } \\
\text { Ayah }\end{array}$ & 0,044 & $\begin{array}{c}\text { Berpengaruh } \\
\text { lemah }\end{array}$ \\
\hline 7 & $\begin{array}{l}\text { Penghasilan } \\
\text { Ibu }\end{array}$ & 0,268 & $\begin{array}{c}\text { Berpengaruh } \\
\text { lemah }\end{array}$ \\
\hline 8 & $\begin{array}{l}\text { Keanggotaan } \\
\text { Organisasi }\end{array}$ & $-0,066$ & $\begin{array}{c}\text { Tidak } \\
\text { berpengaruh }\end{array}$ \\
\hline 9 & $\begin{array}{l}\text { Status Tempat } \\
\text { Tinggal }\end{array}$ & 0,201 & $\begin{array}{c}\text { Berpengaruh } \\
\text { lemah }\end{array}$ \\
\hline
\end{tabular}

Untuk menentukan nilai koefisien jalur di luar model ( $\rho$ yl $\varepsilon 1)$ menggunakan rumus berikut:

$$
(\rho \mathrm{y} 1 \varepsilon 1)=\sqrt{(1-0,173}=0,827
$$

Nilai 0,173 adalah nilai koefisien determinasi regresi linear (R2). Maka dari hasil tersebut dapat disimpulkan bahwa secara parsial variabel bebas berpengaruh terhadap variabel terikat. Dikarenakan besaran pengaruhnya yakni 0,173 dan hampir mendekati 0 , maka pengaruhnya tergolong lemah. Nilai 0,827 menujukkan besaran pengaruh diluar model, karena nilai mendekati 1 menunjukkan pengaruh diluar model termasuk kuat.

Setelah dimasukkan nilai standardized coefficients dan nilai koefisien jalur di luar model ( $\rho$ yle1) didapatkan persamaan sebagai berikut:

$$
\mathrm{Y} 1=-0,010 \mathrm{X} 1+-0,105 \mathrm{X} 2+-0,089 \mathrm{X} 3+
$$
$0,043 \mathrm{X} 4+0,250 \times 5+0,044 \mathrm{X} 6+$

$$
0,268 \times 7+0,268 \times 8+0,201 \times 9+
$$

$0,827 \varepsilon 1$

Dari persamaan tersebut dapat dihitung pengaruh total variabel bebas terhadap variabel terikat. Jumlah pengaruh total yang didapatkan adalah 1,429. Secara spesifik pengaruh antara satu variabel dengan variabel lainnya dapat dilihat pada nilai standardized coefficients. Jika nilai Beta mendekati 0 maka pengaruhnya secara parsial tergolong lemah, dan sebaliknya jika mendekati 1 
maka pengaruhnya secara parsial tergolong kuat. Jika angka Beta dibawah 0 dapat dikatakan secara parsial tidak ada pengaruh.

Dari hasil analisis didapat ada 5 variabel demografi yang memiliki pengaruh walaupun lemah yakni variabel pekerjaan ayah, pekerjaan ibu, penghasilan ayah, penghasilan ibu, dan status tempat tinggal. Selain variabel tersebut tidak ada yang berpengaruh. Pengujian secara simultan (keseluruhan) didapatkan bahwa variabel latar belakang secara bersama-sama berpengaruh terhadap kesadaran lingkungan.

Hal ini dikarenakan nilai signifikansi yang didapat $0,039<0,05$. Selanjutnya pengujian secara parsial berdasarkan nilai signifikansi yang tertera pada Tabel 5 didapatkan hasil bahwa hanya variabel pekerjaan ibu, penghasilan ibu dan status tempat tinggal yang berpengaruh secara parsial terhadap kesadaran lingkungan. Selebihnya tidak memiliki pengaruh karena nilai signifikansi $>0,05$.

Tabel 5 Nilai signifikansi dari analisis jalur

\begin{tabular}{|c|l|c|c|}
\hline No & Variabel & $\begin{array}{c}\text { Nilai } \\
\text { Signifi } \\
\text { kansi }\end{array}$ & Keterangan \\
\hline 1 & $\begin{array}{l}\text { Jenis } \\
\text { Kelamin }\end{array}$ & 0,917 & $\begin{array}{c}\text { Tidak } \\
\text { berpengaruh }\end{array}$ \\
\hline 2 & $\begin{array}{l}\text { Pendidikan } \\
\text { Ayah }\end{array}$ & 0,294 & $\begin{array}{c}\text { Tidak } \\
\text { berpengaruh }\end{array}$ \\
\hline 3 & $\begin{array}{l}\text { Pendidikan } \\
\text { Ibu }\end{array}$ & 0,368 & $\begin{array}{c}\text { Tidak } \\
\text { berpengaruh }\end{array}$ \\
\hline 4 & $\begin{array}{l}\text { Pekerjaan } \\
\text { Ayah }\end{array}$ & 0,664 & $\begin{array}{c}\text { Tidak } \\
\text { berpengaruh }\end{array}$ \\
\hline 5 & $\begin{array}{l}\text { Pekerjaan } \\
\text { Ibu }\end{array}$ & 0,013 & Berpengaruh \\
\hline 6 & $\begin{array}{l}\text { Penghasilan } \\
\text { Ayah }\end{array}$ & 0,659 & $\begin{array}{c}\text { Tidak } \\
\text { berpengaruh }\end{array}$ \\
\hline 7 & $\begin{array}{l}\text { Penghasilan } \\
\text { Ibu }\end{array}$ & 0,010 & Berpengaruh \\
\hline 8 & $\begin{array}{l}\text { Keanggotaa } \\
\text { n } \\
\text { Organisasi }\end{array}$ & 0,512 & $\begin{array}{l}\text { Tidak } \\
\text { berpengaruh }\end{array}$ \\
\hline 9 & $\begin{array}{l}\text { Status } \\
\text { Tempat } \\
\text { Tinggal }\end{array}$ & 0,045 & Berpengaruh \\
\hline
\end{tabular}

Dari hasil analisis regresi linear berganda dan analisis jalur dapat disimpulkan adanya hubungan antara variabel latar belakang dengan kesadaran lingkungan, walaupun lemah. Dalam menganalisis temuan tersebut variabel-variabel yang berpengaruh perlu dipilah secara garis besar. Variabel pekerjaan dan penghasilan dapat diklasifikasikan erat kaitannya dengan faktor sosioekonomi, sedangkan status tempat tinggal dapat diklasifikan ke dalam faktor gaya hidup atau kondisi lingkungan.

Dalam penelitian ditemukan bahwa mayoritas orang tua responden $(71 \%$ ayah dan $73 \%$ ibu) berstatus sebagai non PNS. Kemudian 32\% penghasilan ayah dari responden kurang dari 1 juta rupiah sedang $61 \%$ penghasilan ibu responden kurang dari 1 juta rupiah. Selanjutnya $65 \%$ mahasiswa tinggal di tempat kos atau asrama. Dapat dikatakan mayoritas responden berasal dari keluarga menengah ke bawah.

Sebagaimana yang dikatakan Sulastri (2016) bahwa ada beberapa faktor yang mempengaruhi kesadaran lingkungan, yaitu: (1) faktor ketidaktahuan, (2) faktor kemiskinan, (3) faktor kemanusiaan; dan (4) faktor gaya hidup. Temuan tersebut sejalan dengan temuan penelitian dimana kesadaran lingkungan mahasiswa masuk dalam kriteria sedang, skor rata-rata mencapai $66,43 \%$.

Wibowo (2009) menyatakan faktor-faktor situasional, seperti keadaan ekonomi, tekanan sosial dan peluang yang tersedia, dapat menghambat atau memperkuat kemungkinan munculnya perilaku yang bertanggungjawab. Perilaku yang bertanggungjawab merupakan hasil dari transaksi terus menerus antara faktor internal individu dengan faktor situasional.

Senada hal tersebut Aminrad, dkk. (2014) mengatakan secara umum dapat dikatakan bahwa kemiskinan dapat menyebabkan beberapa masalah sosial dan kesehatan. Hal ini menjadi konsekuensi 
dari kualitas lingkungan yang buruk. Lingkungan tidak bisa bebas dari pencemaran, kecuali masyarakat telah dapat merasakan dan sadar akan konsekuensi dari pencemaran lingkungan. Selain itu faktor sosio-ekonomi turut juga mempengaruhi akses pendidikan. Selain itu Aminrad, dkk. (2014) dalam penelitiannya menyebut ada hubungan signifikan antara pendidikan dengan pendapatan orang tua, dapat dikatakan pendapatan orang tua dapat mempengaruhi pendidikan siswa.

Terkait kondisi tempat tinggal, dalam penelitian ditemukan bahwa mayoritas responden tinggal di tempat kos atau asrama yang berarti jauh dari orang tua, sehingga hal ini turut mempengaruhi karakter mahasiswa. Indriyani (2014) mengatakan anak yang tinggal bersama orang tua akan lebih mendapatkan pengawasan dalam aktivitas mereka, sehingga mereka lebih terarah terutama dalam pendidikan.

Gea (2011) menyebut banyak perilakuperilaku dipengaruhi oleh pola-pola dan aturan yang dipelajari di tengah-tengah masyarakat yang akhirnya secara otomatis terpraktekkan tanpa disengaja. Lingkungan tempat tinggal erat kaitannya dengan interaksi antara anggota keluarga, teman dan masyarakat, kesemuanya merupakan agen penting dalam sosialisasi. Interaksi individu dengan berbagai agen sosialisasi juga ikut membantu menciptakan budaya hidup. Handayani (2008) menambahkan pada umumnya individu cenderung memiliki sikap yang konformis atau searah dengan orang yang mereka anggap penting di lingkungan mereka. Kecenderungan ini memotivasi mereka untuk berafiliasi sekaligus menghindari konflik dengan orang tersebut.

Terkait tidak adanya hubungan antara jenis kelamin dengan kesadaran lingkungan. Ali (2015) dalam penelitiannya menemukan bahwa tidak ada perbedaan signifikan antara jenis kelamin dan lokasi sekolah dengan kesadaran lingkungan. Hal ini juga didukung penelitian yang telah dilakukan Aminrad, dkk. (2010), ia mengemukakan tidak ada perbedaan yang signifikan antara siswa laki-laki dan perempuan dalam kesadaran lingkungan. Dapat dikatakan responden laki-laki dan perempuan memiliki kesadaran lingkungan yang hampir sama. Hal ini menunjukkan tingkat pembelajaran dan minat dalam isu-isu lingkungan tidak ada hubungannya dengan gender.

Terkait temuan bahwa keanggotan organisasi tidak berhubungan dengan kesadaran lingkungan, hal ini sangat berkait dengan individu sendiri. Perilaku individu tidak selalu mencerminkan organisasi. Pitaloka (2013) mengatakan pada dasarnya manusia itu unik; masing-masing memilki karakter yang berbeda yang dibentuk oleh lingkungan, pengalaman, pendidikan dan lain-lain. Keberagaman yang ditimbulkan dari perbedaan individu dapat membawa tantangan bagi organisasi.

Emosi dan sikap yang ditunjukkan individu dalam suatu organisasi secara spesifik akan mempengaruhi perilaku dan berdampak lebih lanjut pada kinerja individu tersebut dalam organisasi tersebut. Dalam hal ini termasuk tugas organisasi mengelola emosi-emosi individu dengan bijak, cerminan individu tidak selalu mencerminkan organisasi.

\section{SIMPULAN}

Terdapat hubungan antara variabel demografi dengan kesadaran lingkungan, walaupun lemah. Ada 5 variabel sosiografi yang memiliki hubungan dengan kesadaran lingkungan yakni variabel pekerjaan ayah, pekerjaan ibu, penghasilan ayah, penghasilan ibu dan tempat tinggal. Kemudian hanya 3 variabel yang berpengaruh secara parsial (faktor tunggal) yakni pekerjaan ibu, penghasilan ibu dan status tempat tinggal. Dapat disimpulkan faktor-faktor situasional, seperti keadaan ekonomi, tekanan sosial dan peluang yang tersedia, dapat menghambat atau memperkuat 
kemungkinan munculnya perilaku yang telah dipelajari di tengah-tengah masyarakat yang bertanggungjawab. Selain itu banyak perilaku- akhirnya secara otomatis terpraktekkan tanpa perilaku dipengaruhi oleh pola-pola dan aturan yang disengaja.

\section{DAFTAR PUSTAKA}

Adeolu A. T., Enesi D. O. dan Adeolu M. O. 2014. Assessment of Secondary School Students' Knowledge, Attitude and Practice towards Waste Management in Ibadan, Oyo State, Nigeria, Journal of Research in Environmental Science and Toxicology, 3(5) : 66-73

Ahmad, J., Noor, M. S. dan Ismail, N. 2015. Investigating Students' Environmental Knowledge, Attitude, Practice and Communication, Asian Social Science, 11(16)

Ali, A.R. 2015. Environmental Awareness Level amongst Secondary School Students in Terengganu, Malaysia Based on Different Variables. International Journal of Education and Research, 3(3) : 135-152

Aminrad, Z., Azizi, M., Wahab, M., Huron, R.dan Nawawi, M. 2010. Environmental Awareness and Attitude among Iranian Students in Malaysian Universities, Environment Asia, 3(1) : 110

Aminrad, Z., Zarina, S. dan Hadi, A.S. 2014. Environmental Perceptions of Teenagers: The Effects of Family Income and Parents' Education. International Journal in Physical \& Applied Sciences, 1(1) : 1-18

Boiyo, V., Koech, M. dan Manguriu, D. 2015. Environmental Attitudes and Ecological Behaviour among Students: A Case Study of Kibera and Kasarani Division in Nairobi, Kenya. International Journal of Interdisciplinary Research and Innovations, 3(1) : 50-59

Handayani, S. 2008. Hubungan Pengetahuan, Sikap, Minat dan Motivasi Belajar dengan Prestasi Belajar Mata Kuliah KDM I pada Mahasiswa Semester I Akper Giri Satria Husada Wonogiri. Tesis. Solo: Program Pascasarjana Universitas Sebelas Maret

Hasan, A., Juahir, H. dan Jamaludin, N. S. 2009. The Level of Environmental Awareness Among Students to Fulfill the Aspiration of National Philosophy of Education, American Journal of Scientific Research, (5) : 50-58

Indriyani, R. 2014. Pengaruh Asal Sekolah dan Tempat Tinggal terhadap Prestasi Belajar Mahasiswa Prodi DIII Kebidanan Universitas Wiraraja Sumenep. Tesis. Solo: Program Pascasarjana Universitas Sebelas Maret

Gea, A.A. 2011. Enculturation Pengaruh Lingkungan Sosial terhadap Pembentukan Perilaku Budaya Individu. Humaniora, 2(1) : 139-150

Kumarand, A. dan Malaviya, P. 2015. Assesment of Environmental Awareness and Attitude Among The Inhabitants of Transport Nagar Slum (Narwal) Jammu (J\&K), International Journal of Recent Scientific Research, 6(6) : 4910-4914

Mangunjaya, F. M., Alikodra, H. S., Amin, A. A. Dan Abbas, A. S. 2013. Kesadaran Lingkungan di Kalangan Santri terhadap Pembangunan Berkelanjutan, Jurnal Media Konservasi, 18(3) : $127-134$

Morissan. 2012. Metode Penelitian Survey. Jakarta: Prenadamedia Group

Perkasa, M., Agrippina dan Wiraningtyas. 2017. Pembelajaran Kimia Berorientasi Sustainable Development untuk Meningkatkan Kesadaran Siswa Terhadap Lingkungan, Jurnal Sainsmat, 6(2): 63- 72

Pitaloka, E. 2013. Perilaku Organisasi. Modul. Tangerang: Program Studi Manajemen Universitas Pembangunan Jaya 
Pranadji, T. 2005. Pintu Gerbang Pencermatan dan Penguatan Nilai-nilai Budaya Indonesia pada Milenium ke-3, Analisis Kebijakan Pertanian, 3(4) : 313-325

Priyatno, D. 2014. SPSS 22 Pengolah Data Terpraktis. Yogyakarta: CV Andi Offset.

Sulastri. 2016. Model Pendidikan Karakter pada Perkuliahan Kimia Dasar dengan Model Pembelajaran Klarifikasi Nilai untuk Meningkatkan Kesadaran Lingkungan. Disertasi. Bandung: Sekolah Pascasarjana UPI.

Wibowo, I. 2009. Pola Perilaku Kebersihan: Studi Psikologi Lingkungan tentang Penanggulangan Sampah Perkotaan. Makara, Sosial Humaniora, 13(1) : 37-47 